\title{
PENGAMBILAN KEPUTUSAN PRO LIFE PADA REMAJA DENGAN KEHAMILAN TIDAK DIINGINKAN (KTD) DI SEMARANG
}

\author{
DECISION MAKING PRO LIFE IN TEENAGERS WITH UNWANTED PREGNANCY IN SEMARANG
}

\author{
Lia Mulyanti \\ Program Studi Diploma III Kebidanan Fakultas Ilmu Keperawatan dan Kesehatan \\ Universitas Muhammadiyah Semarang \\ Email : liambidan@gmail.com
}

\begin{abstract}
ABSTRAK
Latar Belakang: Masa remaja adalah masa transisi antara masa kanak-kanak dengan dewasa dan relatif belum mencapai tahap kematangan mental dan sosial. Remaja bisa saja mengatakan bahwa seks bebas atau seks pranikah itu aman untuk dilakukan. Namun, bila remaja melihat dan memahami akibat dari perilaku itu,ternyata lebih banyak membawa kerugian. Salah satu resikonya adalah kehamilan di luar nikah. Data yang didapat dari PILAR PKBI pada tahun 2011 dari 79 klien yang datang berkonsultasi dengan KTD terdapat 14 klien remaja yang memutuskan untuk melanjutkan kehamilan. Sedangkan pada tahun 2012 dari 63 klien yang berkonsultasi terdapat 6 klien remaja yang melanjutkan kehamilannya sampai melahirkan. Tujuan: Untuk mengetahui bagaimana pengambilan keputusan pro life pada remaja dengan KTD. Metode Penelitian: penelitian ini menggunakan pendekatan kualitatif dengan desain studi kasus untuk mengumpulkan informasi secara mendalam tentang bagaimana pengalaman pengambilan keputusan pro life pada remaja dengan KTD. Hasil: Pengambilan keputusan untuk melanjutkan kehamilan yang dialami merupakan keputusan yang dibuat oleh orang tua dengan cara menikahkan anak remajanya. Alasan informan mengikuti keputusan yang dibuat oleh orang tua untuk melanjutkan kehamilan yaitu mereka patuh dengan apa yang dikatakan orang tua, takut tambah mengecewakan orang tua. Sebagian besar proses pengambilan keputusan untuk melanjutkan kehamilan dengan kasus KTD tidak melalui konseling dengan tenaga kesehatan atau konselor tetapi orang tua mengambil dari pengalaman riil disekitar yaitu jika ada anak remaja perempuan hamil diluar nikah maka harus segera dinikahkan. Kesimpulan: Pengambilan keputusan pro life pada remaja dengan KTD didasarkan karena mengikuti keputusan yang dibuat oleh orang tua remaja tersebut. Konsekuensi yang ditimbulkan dalam mengambil keputusan untuk melanjutkan kehamilannya antara lain konsekuensi pada pendidikan, psikologis, dan sosial.
\end{abstract}

Kata kunci: Remaja, KTD, Pengambilan Keputusan Pro Life

\begin{abstract}
Background: Adolescence is a period of transition between childhood to adulthood and the relative has not yet reached the stage of maturity mentally and socially. Teens can certainly argue that free sex or premarital sex was safe to do. However, when teens look and understand the implications of that behavior, it turns more to bring losses. One risk is that a pregnancy out of wedlock. Data obtained from PILAR IPPA in 2011 from 79 clients who came to consult with KTD there were 14 juvenile clients who decide to continue the pregnancy. While in the year 2012 from 63 clients who consult clients there are 6 teenagers who continue pregnancy until delivery. Objective: To find out how the pro-life decision making in adolescents with KTD. Methods: This study used a qualitative approach with case study design to gather in-depth information about how the experience of the pro-life decision making in adolescents with KTD. Results: The decision to continue the pregnancy experienced is a decision made by parents with a way to marry his teenage son. Reasons informant follow the decision made by the parents to continue the pregnancy that they are compliant with what the parents, fear of disappointing parents added. Most of the decision to continue the pregnancy with KTD case without counseling by health workers or4 counselors, but parents take on the real experiences around that is if there are adolescent girls get pregnant outside marriage it should soon be married. Conclusion: Pro-life decision making in adolescents with KTD based as it follows the decision made by the parents of teenagers. Their consequences in the decision to continue the pregnancy, among others consequences on educational, psychological, and social.
\end{abstract}

Keywords: Adolescence, KTD, decision making pro life 


\section{PENDAHULUAN}

Unwanted pregnancy atau dikenal sebagai kehamilan yang tidak diinginkan merupakan suatu kondisi dimana pasangan tidak menghendaki adanya proses kelahiran dari suatu kehamilan. Kehamilan ini akibat dari suatu perilaku seksual / hubungan seksual baik yang disengaja atau tidak disengaja (Widyastuti, 2009)

Remaja yang hamil merupakan klien obstetrik yang beresiko tinggi. Remaja hamil juga sering mengekpresikan sikap yang tidak realistik yang dapat ditunjukkan di sekolah, tempat kerja, proses parenting dan proses sosialisasi. Remaja yang mengalami kehamilan tidak diinginkan (KTD), mengalami beberapa perlakuan baik dari pihak laki-laki, keluarga maupun masyarakat secara umum. Remaja perempuan lebih banyak mendapatkan tekanan sosial daripada remaja laki-laki. Sikap sosial terhadap remaja laki-laki cenderung fleksibel dan hak pendidikan bagi remaja laki-laki dipertahankan daripada remaja perempuan. Remaja perempuan yang mengalami KTD memandang diri mereka keluar dari definisi ideal dan menyalahi struktur normatif keluarga dari sudut pandang sosial dan agama. Hal ini menyebabkan ketakutan, kebingungan, stress, rasa malu, rasa bersalah, dan bahkan depresi. Mereka akan lebih cenderung mencari layanan yang aman secara sosial daripada aman secara kesehatan fisik (PKBI, 2011)

Data yang didapat dari PILAR PKBI pada tahun 2011 dari 79 klien yang datang berkonsultasi dengan KTD terdapat 14 klien remaja yang memutuskan untuk melanjutkan kehamilan. Sedangkan pada tahun 2012 dari 63 klien yang berkonsultasi terdapat 6 klien remaja yang melanjutkan kehamilannya sampai melahirkan.(Cristina, 2009)

\section{METODE PENELITIAN}

Penelitian ini menggunakan pendekatan kualitatif dengan desain studi kasus untuk mengumpulkan informasi secara mendalam tentang bagaimana pengalaman dan perilaku remaja dengan KTD. Peneliti menggunakan studi kasus dengan pendekatan life history dan menganalisanya dengan tematik.karena dengan bercerita tentang perjalanan hidup sendiri dari proses pacaran, keluarga, lingkungan masyarakat adalah cara yang efektif dan tradisional bagi orang untuk berbagi dan mengaskan ide, isu, dan nilai-nilai dari apa yang dialami oleh mereka (Moleong LJ, 2005)

\section{HASIL DAN PEMBAHASAN}

\section{Karateristik Informan}

Tabel 1. Karateristik Informan Utama

\begin{tabular}{|c|c|c|c|c|c|c|c|}
\hline $\begin{array}{l}\mathrm{N} \\
\mathrm{O}\end{array}$ & $\begin{array}{l}\text { Kode } \\
\text { infor } \\
\text { man }\end{array}$ & Umur & $\begin{array}{c}\text { Jml } \\
\text { saudara } \\
\text { dlm klg }\end{array}$ & $\begin{array}{c}\text { Pertam } \\
\text { a kali } \\
\text { pacaran }\end{array}$ & $\begin{array}{c}\mathrm{Jml} \\
\mathrm{pac} \\
\mathrm{ar}\end{array}$ & $\begin{array}{l}\text { Umur } \\
\text { pacar }\end{array}$ & $\begin{array}{l}\text { Pendi } \\
\text { dikan }\end{array}$ \\
\hline 1 & IU1 & 14 th & $\begin{array}{c}\text { Anak } \\
\text { tunggal }\end{array}$ & $\begin{array}{c}\text { SMP } \\
\text { kelas 1 }\end{array}$ & 2 & 17 th & SMP \\
\hline 2 & IU2 & 16 th & $\begin{array}{c}\text { Anak ke } 2 \\
\text { dari } 3\end{array}$ & $\begin{array}{l}\text { SMA } \\
\text { kelas } 2\end{array}$ & 1 & 21 th & SMA \\
\hline 3 & IU3 & 16 th & $\begin{array}{c}\text { Anak ke } 1 \\
\text { dari } 2\end{array}$ & $\begin{array}{c}\text { SMP } \\
\text { kelas 1 }\end{array}$ & 3 & 18 th & SMA \\
\hline 4 & IU4 & 15 th & $\begin{array}{c}\text { Anak ke } 2 \\
\text { dari } 2\end{array}$ & $\begin{array}{c}\text { SMP } \\
\text { kelas 1 }\end{array}$ & 1 & 18 th & SMP \\
\hline 5 & IU5 & 15 th & $\begin{array}{c}\text { Anak ke } 3 \\
\text { dari } 4\end{array}$ & $\begin{array}{c}\text { SMP } \\
\text { kelas } 2\end{array}$ & 2 & 22 th & SMP \\
\hline 6 & IU6 & 14 th & $\begin{array}{c}\text { Anak ke } 2 \\
\text { dari } 2\end{array}$ & $\begin{array}{l}\text { SMP } \\
\text { kelas } 1\end{array}$ & 3 & 18 th & SMP \\
\hline 7 & IU7 & 17 th & $\begin{array}{c}\text { Anak ke } 3 \\
\text { dari } 3\end{array}$ & $\begin{array}{c}\text { SMP } \\
\text { kelas } 3\end{array}$ & 3 & 20 th & SMA \\
\hline
\end{tabular}

Dari tabel diatas dapat dilihat bahwa 7 informan utama yang berusia dibawah atau sama dengan 15 tahun ada 4 informan dan yang berusia diatas 15 tahun ada 3 informan. Berdasarkan perbedaan usia yang berusia kurang atau sama dengan 15 tahun berbeda dengan informan yang berusia diatas 15 tahun ternyata memiliki respon berbeda dalam mengahdapi KTD yang mereka alami, baik dari 
diri mereka sendiri juga dari orang tua responnyapun berbeda.

Berdasarkan umur dari informan utama diketahui bahwa mereka mengalami KTD pada saat berusia, 14 tahun, 15 tahun, 16 tahun dan 17 tahun. Berdasarkan kareteristiknya remaja yang mengalami KTD adalah remaja dalam tahap pertengahan (14 sampai 17 tahun). Masa ini dimana perkembangan fisik mereka bagitu menonjol. Remaja akan cemas dengan perkembangan fisiknya, sekaligus bangga bahwa hal itu menunjukkan bahwa ia memang bukan anak-anak lagi.. pada masa ini emosi remaja menjadi sangat labil akibat dari perkembangan hormon-hormon seksualnya yang begitu pesat. Keinginan seksualnya juga semakin kuat. Pada remaja wanita ditandai dengan datangnya menstruasi pertama sedangkan pada remaja laki-laki ditandai dengan mimpi basah yang pertama. Remaja menjadi bingung dan malu akan hal ini, sehingga orang tua harus mendampingi serta memberikan pengertian yang baik dan benar mengenai seksualitas (Nirwana BA, 2011)

Tabel 2. Karateristik Informan Pendukung

\begin{tabular}{|c|c|c|c|c|c|c|}
\hline $\begin{array}{l}\mathrm{N} \\
\mathrm{o}\end{array}$ & $\begin{array}{l}\text { Kode } \\
\text { Infor } \\
\text { man }\end{array}$ & $\begin{array}{l}\text { Umur } \\
(\mathrm{Th})\end{array}$ & $\begin{array}{l}\text { Agam } \\
\text { a }\end{array}$ & $\begin{array}{c}\text { Status } \\
\text { Perkaw } \\
\text { inan }\end{array}$ & $\begin{array}{c}\text { Pendidik } \\
\text { an } \\
\text { Terakhir }\end{array}$ & $\begin{array}{c}\text { Pekerjaa } \\
n\end{array}$ \\
\hline 1 & IP1 & 35 th & Islam & Intack & SMA & Swasta \\
\hline 2 & IP2 & 40 th & Islam & Intack & SD & $\begin{array}{c}\text { Wiraswa } \\
\text { sta }\end{array}$ \\
\hline 3 & IP3 & 33 th & Islam & Intack & SMA & Swasta \\
\hline 4 & IP4 & 40 th & Islam & Intack & SMA & $\begin{array}{c}\text { Pedagan } \\
\mathrm{g}\end{array}$ \\
\hline 5 & IP5 & 47 th & Islam & Intack & diploma & $\begin{array}{c}\text { PNS } \\
\text { (Pegawai } \\
\text { Negeri } \\
\text { Sipil) }\end{array}$ \\
\hline 6 & IP6 & 37 th & Islam & Intack & SMA & $\begin{array}{c}\text { Wiraswa } \\
\text { sta }\end{array}$ \\
\hline 7 & IP7 & 45 th & Islam & Intack & diploma & Swasta \\
\hline
\end{tabular}

Dari hasil penelitian didapatkan bahwa rata-rata tingkat pendidikan dari informan pendukung adalah baik hal ini dilihat dari 7 orang informan pendukung 4 diantaranya lulusan SMA, 2 lulusan diploma, dan hanya 1 yang lulusan SD. Hal ini menunjukkan bahwa pendidikan merupakan pengembangan diri dari individu dan kepribadian yang dilaksanakan secara sadar dan penuh tanggung jawab untuk meningkatkan pengetahuan, sikap dan ketrampilan serta nilai-nilai sehingga mampu menyesuaikan diri dengan lingkungan. Ibu dengan pendidikan yang relatif tinggi cenderung memiliki kemampuan untuk menggunakan sumber daya keluarga yang lebih baik dibandingkan dengan ibu yang berpendidikan rendah. Ibu dengan tingkat pendidikannya rendah, memberi dampak dalam mengakses pengetahuan khususnya dibidang kesehatan untuk penerapan dalam kehidupan keluarga.

\section{Konsekuensi Pengambilan Keputusan Pro Life pada Remaja dengan KTD}

Dari hasil penelitian didapatkan bahwa usia informan saat melakukan hubungan seksual sangat dini yaitu antara 14-16 tahun. Dimana usia yang termuda yaitu 14 tahun. Berdasarkan hasil penelitian tersebut dapat terlihat bahwa sangat dibutuhkannya pendidikan kesehatan reproduksi usia remaja tidak hanya tentang perubahan organ reproduksi tetapi juga terkait dengan kehamilan yang tidak diinginkan (KTD).

Usia reproduksi sehat adalah usia 20-35 tahun dimana oragn reproduksi sudah berkembang dengan sempurna. Sedangkan hasil dari wawancara dengan informan didapatkan bahwa usia yang termuda saat melakukan hubungan seksual yaitu usia 14 tahun. Hubungan seksual pada usia kurang dari 20 tahun merupakan salah satu faktor resiko terjadinya kanker servik pada wanita yang dapat berakibat lebih buruk pada kesehatan reproduksi wanita sehingga perlu kiranya meningkatkan informasi perilaku seksual sehat bagi remaja sedini mungkin, supaya terhindar dari perilaku seksual yang dapat membahayakan kesehatan reproduksinya kelak. 
Dari hasil penelitian respon dari informan saat mengetahui kalau dirinya hamil yaitu mereka merasakan stress, bingung, kaget, merasa bersalah, dan menyesal dengan kehamilan yang informan alami.

Diketahuinya adanya kehamilan yang merupakan kehamilan yang tidak diinginkan hal ini akan menimbulkan resiko santara lain resiko medis, psikologis, psikososial,dan masa depan remaja dan janin. Pada resiko medis akan menimbulkan resiko aborsi tidak aman berkontribusi pada kematian dan kesakitan ibu, gangguan kesehatan. Pada psikologis akan menimbulkan resiko merasa bersalah, depresi, marah agresi,remaja atau calon ibu merasa tidak inggin dan tidak siap untuk hamil. Psikososial akan berdampak ketegangan mental dan kebingungan akan peran sosial yang tibatiba berubah, tekanan dari masyarakat yang mencela dan menolak keadaan tersebut, dikucilkan dari masyarakat yang mencela dan menolak keadaan tersebut, dikucilkan dari masyarakat dan hilang kepercayaaan diri. Masa depan remaja dan janin juga akan beresiko terganggunya kesehatan, resiko kelainan janin dan tingkat kematian bayi yang tinggi, pernikahan remaja dan pengguguran kandungan, putus sekolah, bila bayi dilahirkan, masa depan anak mungkin saja terlantar,perkembangan bayi tertahan, bayi terlahir dengan berat rendah.(Kusmiran E, 2012)

Ketika keluarga mengetahui, respon keluarga bermacam-macam, baik verbal maupun non verbal, baik dilakukan secara terbuka maupun tertutup. Respon non verbal ditunjukkan melalui sikap. Kata-kata yang dikeluarkan berupa pertanyaan, kata-kata kasar, menyalahkan dan mengeluh. Sedangkan respon melalui sikap ditunjukkan melalui tatapan tajam dan pandangan asing. Respon secara tertutup dilakukan dengan cara "menggosip", diam, dan acuh tak acuh (Sarwono SW, 2007)

Proses pengambilan keputusan melanjutkan kehamilan pada remaja dengan kasus KTD tidaklah mudah. Semua informan utama memilih untuk melanjutkan kehamilan yang dialami oleh dirinya, walaupun respon pasangan atau orang tua ada yang tidak mendukung untuk meneruskan kehamilan yang dialaminya

Hal ini sependapat dengan penelitian Arsani yang menunjukkan bahwa orang tua khususnya ibu, teman dekat dan pasangan seksual memiliki pengaruh yang berarti pada keputusan yang diambil remaja yang hamil.

Dari hasil wawancara mendalam (indepth interview) diperoleh informasi bahwa konsekuensi yang ditimbulkan dengan mengambil keputusan untuk pro life pada kehamilan dengan KTD dari ketujuh informan menjelaskan bahawa konsekuensi yang mereka dapatkan dari pengambilan keputusan pro life antara lain tidak bisa melanjutkan sekolah ke jenjang selanjutnya, terancam dikeluarkan (drop out) dari sekolah.

Kehamilan remaja dengan KTD dapat menyebabkan terganggunya masa depan remaja. misalnya kehamilan pada remaja sekolah, remaja akan terpaksa meninggalkan sekolah, hal ini berarti terhambat atau bahkan mungkin tidak tercapainya cita-citanya. Sementara itu, kehamilan remaja juga mengakibatkan lahirnya anak yang tidak diinginkan, sehingga akan berdampak pada kasih sayang ibu terhadap anak tersebut. Masa depan anak ini dapat mengalami hambatan yang menyedihkan dan belum siap menjadi ibu (Kusmiran E, 2012)

\section{Motifasi untuk Pengambilan Keputusan Pro life}

Hasil penelitian menunjukkan bahwa alasan dari informan mengikuti pendapat atau keputusan dari orang tua karena tidak ingin menambah beban dari orang tua, masih berstatus sebagai pelajar, sehingga tidak ada pilihan lain selain mengikuti apa yang telah diputuskan oleh orang tua mereka. Hasil serupa didapatkan oleh peneliti saat melakukan wawancara dengan informan pendukung, berbagai macam alasan mengapa anak 
remajanya setuju dengan keputusan yang dibuat oleh orang tua mereka karena perasaan takut terhadap orang tua, adanya paksaan harus setuju dengan apa yang diputuskan oleh orang tua seperti yang diungkapkan oleh salah seorang informan pendukung, dia mengungkapkan bahwa seorang anak harus patuh dengan apa yang dikatakan oleh orang tua walaupun dengan terpaksa karena semua itu demi kebaikan dari anak remaja tersebut.

Ketika kehamilan terungkap, respon dari orang tua atau orang lain biasanya negatif. Keputusan selanjutnya adalah orang tua remaja perempuan biasanya memusyawarahkan masalah ini dengan pacar anak remajanya dan orang tua sang pacar. Keluarga termasuk orang terdekat dengan remaja. Pemberian makna terhadap kehamilan dan reaksi keluarga terhadap kehamilan terutama yang tidak diinginkan menjadi sangat penting dalam pengambilan keputusan terhadap menghadapi KTD. (Nirwana BA, 2011)

Hal ini sesuai dengan penelitian khisbiyah dan wijayanto terhadap remaja di DIY (Daerah Istimewa Yogyakarta). Hasil penelitian menyebutkan bahwa banyak orang tua yang kecewa dan marah besar begitu mendengan kehamilan anak remajanya. Perasaan itu timbul karena dalam pandangan masyarakat umum, remaja perempuan yang hamil adalah balck sheep di tengah keluarganya, yang secara telah mencoreng nama baik keluarga

\section{Dukungan untuk Memilih Melanjutkan Kehamilan (Pro life)}

Hasil penelitian menunjukkan bahwa informan utama mendapatkan dukungan dari pasangan maupun orang tua. Bentuk dukungan dari orang tua yaitu dengan menemani informan memeriksakan kehamilannya, sedangkan bentuk dukungan dari pasangannya adalah dengan bersedia untuk menikahi informan. Hal ini menunjukkan bahwa posisi pasangan atau pacar cukup dominan dalam mendukung pengambilan keputusan remaja untuk melanjutkan kehamilan, yang artinya dapat menentukan nasib remaja dan bayi yang dikandungnya. Posisi ini merupakan bentuk pertanggung jawaban atas perbuatan atau perilaku seksual yang dilakukannya, yang sangat diharapkan oleh remaja dengan KTD. Posisi orang tua sebagai pembuat keputusan sekaligus juga sebagai mediator antara remaja dengan KTD dan pasangannya atau pacarnya, agar bertanggung jawab pada kehamilan remaja yang mengalami KTD.

Dukungan emosional, mencakup ungkapan empati, kepedulian dan perhatian orang-orang yang bersangkutan kepada anggota keluarga yang mengalami masalah kesehatan, misalnya umpan balik dan penegasan dari anggota keluarga. Keluarga merupakan tempat yang aman untuk istirahat serta pemulihan penguasaan emosi. Remaja membutuhkan dukungan yang berbeda dari masa sebelumnya, karena pada saat ini remaja sedang mencari dalam mengeksplorasi diri sehingga dengan sendirinya keterikatan dengan orang tua berkurang. Pengertian dan dukungan orang tua, sangat bermanfaat bagi perkembangan remaja. (Freadman M, 2005)

\section{Sumber Informasi tentang Pemilihan Pro life pada Kasus Remaja dengan KTD}

Dari hasil wawancara mendalam bahwa lima dari tujuh informan utama mengatakan jika mereka tidak mempunyai informasi tentang pemilihan pro life pada kasus kehamilan KTD.sedangkan dua informan utama diantaranya telah mendapatkan konseling dari pihak puskesmas tentang kehamilan tidak diinginkan oleh bidan yang bertugas di puskesmas tersebut.

\section{SIMPULAN}

1. Karateristik utama dalam penelitian ini adalah remaja yang mengalami KTD yang melanjutkan kehamilan. Usia informan utama antara 14-17 
tahun. Empat informan berusia dibawah atau sama dengan 15 tahun, dan tiga informan berusia diatas 15 tahun. Semua informan utama masih berstatus sebagai pelajar

2. Konsekuensi yang ditimbukan antara lain konsekuensi pendidikan, psikologis, dan sosial. Pada konsekuensi pendidikan semua informan dikeluarkan dari sekolah. Dari 4 informan yang berusia dibawah 15 tahun hanya 1 informan yang ingin melanjutkan sekolah kejenjang yang lebih tinggi dan 1 Informan yang berusia 15-17 tahun yang ingin melanjutkan sekolah ke perguruan tinggi. Konsekuensi psikologis dan sosial adalah stress, perasaan malu dengan masyarakat sekitar.

3. Tujuh informan utama mengikuti pendapat yang disampaikan oleh kedua orang tuanya. Orang tua merekalah yang akhirnya membuat keputusan untuk melanjutkan kehamilan dari remaja dengan KTD. Alasan informan mengikuti keputusan yang dibuat oleh orang tua karena takut kepada orang tua ,tidak ingin tambah mengecewakan orang tua dan merasa bersalah dengan KTD.

4. Semua informan utama mendapatkan dukungan dari orang tua. Dukungan yang diberikan orang tua yaitu perhatian terhadap kehamilan yang dialami oleh informan utama. Perhatian yang diberikan seperti mengingatkan jadwal periksa,mengantarkan periksa. Walaupun pada awalnya saat mengetahui kehamilan yang dialami oleh informan respon orang tua marah, kecewa tetapi akhirnya orang tua memberikan dukungan terhadap kehamilan informan.

5. Dari 7 informan utama hanya 2 informan utama yang mendapatkan informasi tentang pemilihan keputusan. Informasi tentang pemilihan keputusan tersebut didapatkan dari tenaga kesehatan yang bekerja di puskesmas.

\section{DAFTAR PUSTAKA}

Widyastuti Y, dkk. Kesehatan Reproduksi. Fitamaya. Yogyakarta. 2009.

Perkumpulan Keluarga Berencana Indonesia (PKBI) Daerah Istimewa Yogyakarta. Studi Kasus Kehamilan Tidak
Diinginkan pada Remaja. PKBI Yogyakarta. 2011.

Cristina K. Tinjauan Yuridis terhadap Aborsi yang Dilakukan oleh Perempuan Korban Kejahatan Perkosaan (Skripsi). Fakultas Hukum Universitas Atmajaya Yogyakarta. Yogyakarta. 2009.

Kusmaryanto. Kontroversi Aborsi. Gramedia Widiasarana Indonesia. Jakarta. 2002.

Nies $\mathrm{M}$ and McEwen M. Community/Public Health Nursing ( $6^{\text {th }}$ Edition). Elsevier Inc. St. Louis. 2004.

Sarwono. IImu Kebidanan. Yayasan Bina Pustaka Sarwono Prawirohardjo. Jakarta. 2008.

Widyoningsih. Pengalaman Keluarga Merawat Anak Remaja dengan Kehamilan Tidak Diinginkan (KTD) Di Kabupaten Cilacap Provinsi Jawa Tengah: Studi Fenomenologi (Tesis). Magister Keperawatan Fakultas Ilmu Keperawatan. Universitas Indonesia. Jakarta. 2011.

Moleong LJ. Metodologi Kualitatif. Remaja Rodakarya. Bandung. 2005.

Nirwana BA. Psikologi Kesehatan Wanita. Nuha Medika. Yogyakarta. 2011.

Kusmiran E. Kesehatan Reproduksi Remaja dan Wanita. Salemba Medika. Jakarta. 2012.

Sarwono SW. Psikologi Remaja. Grafindo Persada. Jakarta. 2007.

Arsani ANLK, dkk. Peranan Program PKPR (Pelayanan Kesehatan Peduli Remaja) Terhadap Kesehatan Reproduksi Remaja di Kecamatan Bulalang 
(Skripsi). Fakultas Olahraga dan Kesehatan Universitas Pendidikan Ganesha Singaraja. Singaraja. 2013.

Khisbiyah M dan Wijayanto. Kehamilan Tak Dikehendaki di Kalangan Remaja. Yogyakarta. Pusat Studi Kependudukan dan Kebijakan Universitas Gadjah Mada. Yogyakarta. 1997. 